\title{
Thermal behavior and decomposition kinetics of rifampicin polymorphs under isothermal and non-isothermal conditions
}

\author{
Ricardo Alves ${ }^{1}$, Thaís Vitória da Silva Reis ${ }^{2}$, Luis Carlos Cides da Silva ${ }^{3}$, Silvia Storpírtis ${ }^{1}$, Lucildes \\ Pita Mercuri ${ }^{4,5}$, Jivaldo do Rosário Matos ${ }^{3}$
}

\begin{abstract}
${ }^{1}$ Department of Pharmacy, Faculty of Pharmaceutical Sciences, University of São Paulo, ${ }^{2}$ Oswaldo Cruz Faculties, ${ }^{3}$ Department of Fundamental Chemistry, Institute of Chemistry, University of São Paulo, ${ }^{4}$ Federal University of São Paulo, Diadema Campus, ${ }^{5}$ Federal University of São Paulo, São Paulo Campus
\end{abstract}

\begin{abstract}
The thermal behavior of two polymorphic forms of rifampicin was studied by DSC and TG/DTG. The thermoanalytical results clearly showed the differences between the two crystalline forms. Polymorph I was the most thermally stable form, the DSC curve showed no fusion for this species and the thermal decomposition process occurred around $245^{\circ} \mathrm{C}$. The DSC curve of polymorph II showed two consecutive events, an endothermic event $\left(\mathrm{T}_{\text {peak }}=193.9^{\circ} \mathrm{C}\right)$ and one exothermic event $\left(\mathrm{T}_{\text {peak }}=209.4^{\circ} \mathrm{C}\right)$, due to a melting process followed by recrystallization, which was attributed to the conversion of form II to form I. Isothermal and non-isothermal thermogravimetric methods were used to determine the kinetic parameters of the thermal decomposition process. For non-isothermal experiments, the activation energy $\left(\mathrm{E}_{\mathrm{a}}\right)$ was derived from the plot of $\log \beta v_{s} 1 / T$, yielding values for polymorph form I and II of 154 and $123 \mathrm{~kJ} \mathrm{~mol}^{-1}$, respectively. In the isothermal experiments, the $\mathrm{E}_{\mathrm{a}}$ was obtained from the plot of lnt $v$ s $1 / T$ at a constant conversion level. The mean values found for form I and form II were 137 and $144 \mathrm{~kJ} \mathrm{~mol}^{-1}$, respectively.
\end{abstract}

Uniterms: Rifampicin. Tuberculosis. Thermal analysis. Thermal decomposition. Kinetic analysis.

O comportamento térmico de duas formas polimórficas da rifampicina foi estudado por DSC e TG/DTG. Os resultados termoanalíticos mostraram claramente as diferenças entre as duas formas cristalinas. $\mathrm{O}$ polimorfo I é a forma mais estável termicamente, a curva DSC não mostrou a fusão dessa espécie e o processo de decomposição térmica ocorreu próximo a $245^{\circ} \mathrm{C}$. A curva DSC do Polimorfo II apresentou dois eventos consecutivos, um endotérmico $\left(\mathrm{T}_{\text {pico }}=193,9^{\circ} \mathrm{C}\right)$ e outro exotérmico $\left(\mathrm{T}_{\text {pico }}=209,4{ }^{\circ} \mathrm{C}\right)$, devido à fusão seguida de recristalização, a qual foi atribuída à conversão da forma II à forma I. Métodos termogravimétricos isotérmicos e não-isotérmicos foram empregados para determinar os parâmetros cinéticos do processo de decomposição térmica. Para experimentos não-isotérmicos, a energia de ativação ( $\mathrm{E}_{\mathrm{a}}$ ) foi obtida a partir do gráfico de $\log \beta v s \mathrm{~s} / \mathrm{T}$, e os valores 154 e $123 \mathrm{~kJ} \mathrm{~mol}^{-1}$ foram encontrados, respectivamente, para os polimorfos I e II. Para os experimentos isotérmicos, a $\mathrm{E}_{\mathrm{a}}$ foi obtida a partir do gráfico de lnt vs. 1/T a um nível de conversão constante. O valor médio encontrado foi 137 e $144 \mathrm{~kJ} \mathrm{~mol}^{-1}$, respectivamente, para a forma I e forma II.

Unitermos: Rifampicina. Tuberculose. Análise Térmica. Decomposição térmica. Análise cinética.

\section{INTRODUCTION}

Thermal Analysis (TA) is the study of the relationship between a sample property and its temperature as

*Correspondence: L.P. Mercuri. Universidade Federal de São Paulo - Campus Diadema, Rua Prof. Artur Riedel, 275 - Jd. Eldorado - 09972-270 - DiademaSP, Brasil. E-mail: 1pmercuri@gmail.com the sample is heated or cooled in a controlled manner [Rouquerol et al., 2007]. The most widely used techniques for application in the pharmaceutical area are thermogravimetry (TG), differential thermal analysis (DTA) and differential scanning calorimetry (DSC) (Ford, Timmins, 1989; Matos et al., 2009).

Thermogravimetry measures variations in mass as a function of time and/or temperature. The curves obtained 
give information about the composition and thermal stability of the sample, the intermediate products and end residue. The derivative thermogravimetric curve (DTG) is the first derivative of the TG curve. In this curve, the degrees corresponding to variations in mass used by the TG curve are replaced with peaks which determine proportional areas corresponding to mass variations. The DTG curve presents the same information as the TG; however, it allows for separation of the superimposed reactions, since the subtle inflections of TG are emphasized. Thus, the temperatures corresponding to the beginning and end of the reaction can be measured more precisely. Also, it aids in the calculation of mass variation in the case of reaction overlap, since using only the TG curve it is difficult to define the start and end of the reaction.

The DSC, derived from the DTA technique, measures the difference in energy provided to the substance and a reference material (thermally stable), as a function of temperature, while both are being subjected to a controlled temperature program. When the sample undergoes a temperature alteration due to an endothermic or exothermic reaction in response to heating or cooling, the differential heat flux necessary to keep the sample and reference at the same temperature can be measured. The temperature difference between the sample and reference material is due to chemical reactions (decomposition, combustion), change of state (melting, sublimation) or crystalline transitions. These events are expressed in the form of peaks. Regarding heat flux DSC, the upward peaks represent exothermic events, while the downward peaks are characteristic of endothermic events. In the case of second-order transitions, there are changes in the baseline without peaks. For example, the glass transition $\left(\mathrm{T}_{\mathrm{g}}\right)$ is evidenced on the DSC curve as a change in baseline in the endothermic direction.

The area under the peak represents the change in enthalpy, $\Delta \mathrm{H}$, undergone by the sample (heat absorbed or released during the thermal reaction).

Ideally, the information from TG/DTG and DSC should be combined to enable optimal characterization of the materials. Although the TG/DTG detect all types of thermal reactions in terms of variations in mass, the DSC also detects reactions which may or may not be associated with loss of mass, such as physical phenomena. For example, a change in physical state (fusion) can be unequivocally attributed from the DSC curve if losses in mass reactions are not found in the same temperature range on TG/DTG curves. In most cases, interpretation of thermal reactions is difficult without superposition of the TG/DTG and DSC curves obtained under the same experimental conditions.
In the case of drugs and medicines, the TG/DTG and DSC techniques allow evaluation and/or comparison of thermal stabilities of pharmaceutical materials, the acquisition of data on drug/excipient compatibility for the pre-formulation studies, and determination of kinetic parameters (activation energies, frequency factor, and reaction order). This information is useful in pharmaceutical quality control, development of pharmaceutical products and for evaluation of quality of pharmaceutical products from technologic parameters (Venkataram et al., 1995; Araújo et al., 2003; Giron, 1995; Cides et al., 2006).

According to the Panamerican Health organization, $50 \%$ of the cases of tuberculosis in the Americas are found in Peru and Brazil. In 2004, the Ministry of Health estimated that some 50 million Brazilians were infected with Mycobacterium tuberculosis, which ranked Brazil $16^{\text {th }}$ among the 22 countries with the highest levels of tuberculosis (WHO, 2006).

The discovery of rifamycins in the late 1950s led to the synthesis of rifampicin in 1965, and its introduction as a therapy in 1968 (Bujnowski et al., 2003).

Rifampicin is a semi-synthetic antibiotic derived from the rafamycin B family, produced by strains of Nocardia (Streptomyces) mediterranei. It has a wide spectrum antibacterial action including activity against various strains of Mycobacterium. It inhibits the activity of the DNA dependent RNA polymerase enzyme through the formation of a stable complex with this enzyme. This abolishes the synthesis of bacterial RNA. It functions in intra and extracellular microorganisms and in bacteria in latent states or when undergoing the process of division (Zhang, 2005; Bacchi et al., 1998).

Rifampicin has been included in the primary list of essential medications by the World Health Organization and remains the principal drug in the treatment of tuberculosis (Agrawal et al., 2004; WHO, 2007).

The introduction of rifampicin, in combination with isoniazid, into the therapy for tuberculosis reduced the length of treatment necessary from 18-24 months to 6-9 months (Zhang, 2005; Saltini, 2006).

The Minimal Inhibitory Concentration (MIC), from 0.25 to $0.50 \mathrm{mg} / \mathrm{mL}$, was defined as the lowest level among pharmaceutical drugs which inhibits growth of Mycobacterium tuberculosis (Carvalho et al., 2007).

WHO recommendations for the treatment of tuberculosis are based on rifampicin in association with other drugs, mainly isoniazid, pyrazinamide and ethambutol, known as tuberculostatic drugs of first choice, in order to avoid the emergence of strains of resistant bacteria. (WHO, 2007).

Rifampicin is officially designated as 2,7-(epoxypentadeca $[1,11,13]$ trienimino)naphtho[2,1-b]furan- 
1,11(2H)-dione, 5,6,9,17,19,21-hexahydroxy-23-methoxy2,4,12,16,18,20,22-heptamethyl-8-[N-(4-methyl-1-piperazinyl)formimidoyl]-2,7-acetate by the IUPAC.

However, in the literature it is more commonly known as 3-[[(4-methyl-1-piperazinyl)imino]methyl] rifamycin SV, according to the original nomenclature of the rifamycins (Gallo, Radaelli, 1976). The molecular formula is $\mathrm{C}_{43} \mathrm{H}_{58} \mathrm{~N}_{4} \mathrm{O}_{12}$, with a molecular mass of $822.94 \mathrm{~g} / \mathrm{mol}$ $(62.76 \%=\mathrm{C} ; 7.10 \%=\mathrm{H} ; 6.81 \%=\mathrm{N}$ and $23.33 \%=\mathrm{O})$ and its molecular structure is shown in Figure 1.

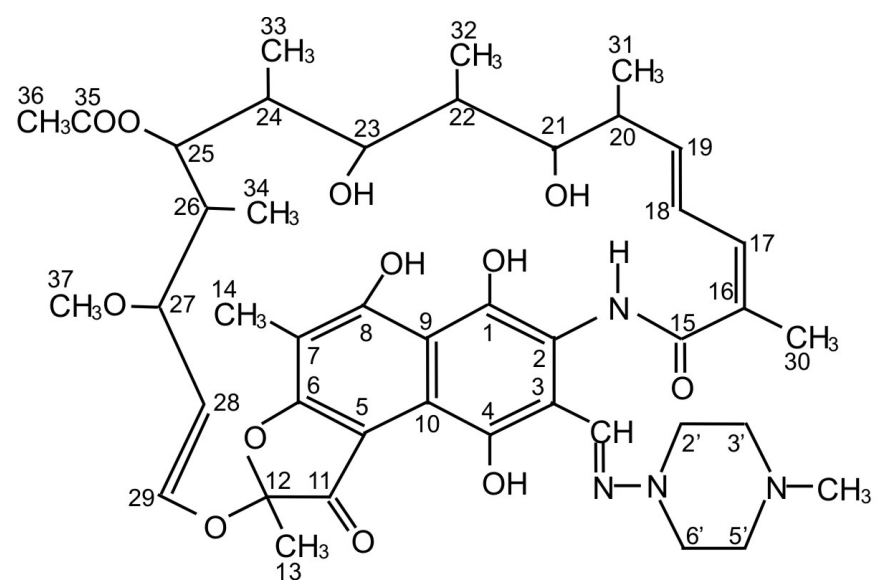

FIGURE 1 - Molecular structure of rifampicim [Agrawal et al., 2004].

Rifampicin is slightly soluble in water and its solubility and stability varies according to $\mathrm{pH}$ due to its amphoteric nature. At a $\mathrm{pH}$ of 2 , its solubility is $100 \mathrm{mg} / \mathrm{mL}$, whereas at $\mathrm{pH} 5.3$ this falls to $4.0 \mathrm{mg} / \mathrm{mL}$, and at $\mathrm{pH} 7.5$, the solubility is $2.8 \mathrm{mg} / \mathrm{mL}$ (Gallo, Radaelli, 1976). In acidic solutions, rifampicin undergoes hydrolysis to yield 3-formyl-rifamycin and 1-amino 4-methylpiperazine. Under alkaline conditions ( $\mathrm{pH}$ of 7.5 to 9.0) rifampicin will oxidize if oxygen is present, becoming rifampicin-quinone. (Gallo, Radaelli, 1976; Singh et al., 2001). Maximum stability of rifampicin is reached in near-neutral solutions. The addition of ascorbic acid to the solution increases the solubility of rifampicin and decreases its oxidation (Gallo, Radaelli, 1976).

Rifampicin exists as a polymorph with two principal forms, I and II, and also in amorphous form (Pelliza et al., 1977). Form I is the most stable, while form II is the most meta-stable. Besides these two principal forms, rifampicin is found as a hydrate and solvate, which convert to amorphous form after removal of the solvent (Henwood et al., 2001).

Recent studies have shown that the polymorphic forms I and II of rifampicin have different solubility in aqueous media (Henwood et al., 2001; Agrawal et al., 2004). These differences in solubility in aqueous media could affect the absorption and bioavailability of the drug when in solid state for oral ingestion (Singh et al., 2001; Agrawal et al., 2004; Panchagnula, Agrawal, 2004).

The objective of this study was to employ TG/DTG and DSC to study the thermal behavior and decomposition kinetics of rifampicin polymorphs under isothermal and non-isothermal conditions.

\section{MATERIAL AND METHODS}

\section{Material}

Rifampicin samples were kindly provided by FURP (form I, batch 142/03 and form II, batch RR327273/0).

\section{Methods}

The DSC curves were obtained on a DSC-50 cell (Shimadzu) using aluminum crucibles with about $2 \mathrm{mg}$ of sample, under dynamic $\mathrm{N}_{2}$ atmosphere $\left(50 \mathrm{~mL} \mathrm{~min}^{-1}\right)$ and heating rate $(\beta)$ of $10^{\circ} \mathrm{C} \mathrm{min}^{-1}$ between 25 to $500{ }^{\circ} \mathrm{C}$. The DSC cell was calibrated using indium (m.p. $156.6^{\circ} \mathrm{C}$, $\Delta \mathrm{H}_{\text {fusion }}=28.54 \mathrm{~J} \mathrm{~g}^{-1}$ ) and zinc (m.p. $419.6^{\circ} \mathrm{C}$ ).

The TG/DTG curves were obtained with a thermobalance model TGA-50 (Shimadzu) in the temperature range of $25-700{ }^{\circ} \mathrm{C}$, using a platinum crucible with approximately $5 \mathrm{mg}$ of sample in a dynamic air atmosphere

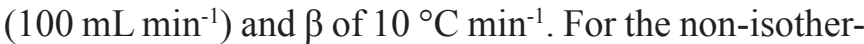
mal kinetic study of the thermal decomposition process for the two polymorphic forms of rifampicin, the Ozawa dynamic method was applied using the TG kinetic analysis program installed on Shimadzu data acquisition system. Six different $\beta$ were used: $2.5,5.0,7.5,10,15$ and $20^{\circ} \mathrm{C}$

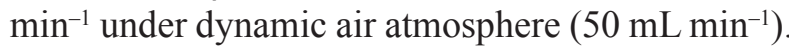

Concerning the kinetic study by isothermic TG, five TG curves were obtained using the following experimental conditions: a) heating of the sample with $\beta$ of $20^{\circ} \mathrm{C} / \mathrm{min}$ from room temperature up to $\mathrm{T}_{\text {isotherm }}-10^{\circ} \mathrm{C}$; b) heating of the sample from $\mathrm{T}_{\text {isotherm }}-10^{\circ} \mathrm{C}$ up to $\mathrm{T}_{\text {isotherm }}$ at $2{ }^{\circ} \mathrm{C} / \mathrm{min}$; c) at the temperature of the isotherm $\left(\mathrm{T}_{\text {isotherm }}\right)$, the heating was kept constant until the initial mass of the sample was reduced by at least $10 \%$. The $\mathrm{T}_{\text {isotherm }}$ elected for polymorph I were $200,205,210,220$ and $230^{\circ} \mathrm{C}$, given that the TG/DTG curves obtained (Figure 2) at $10{ }^{\circ} \mathrm{C} / \mathrm{min}$ showed that thermal decomposition of the sample began at a temperature of around $240{ }^{\circ} \mathrm{C}$. Using the same criteria for polymorph II, the $\mathrm{T}_{\text {isotherm }}$ chosen were $175,180,185,190$ and $195{ }^{\circ} \mathrm{C}$.

The infrared absorption spectra of the rifampicin polymorphs and the intermediates from the thermal decomposition process were obtained using model MB102 
equipment (Bomem) in the region of 4000 to $400 \mathrm{~cm}^{-1}$. $\mathrm{KBr}$ pellets containing small amount of the samples were prepared. The studies were done at the Laboratories of Analytic Center of the Chemistry Institute of the University of São Paulo.

\section{RESULTS AND DISCUSSION}

\section{Thermal behavior of polymorphs I and II}

The TG/DTG and DSC curves of rifampicin polymorph I are shown in Figure 2. The TG/DTG curves indicated that this crystalline form is thermally stable up to around $240^{\circ} \mathrm{C}$ and that the thermal decomposition process occurred in two stages. The first stage occurred rapidly between 240 and $275^{\circ} \mathrm{C}$, with a mass loss of $19.5 \%$. However, the second step occurred slowly between 275 and $625^{\circ} \mathrm{C}$ with gradual mass loss of around $80 \%$. The residual amount of approximately $0.5 \%$ was partially derived from elementary carbon formed during the second step of the thermal decomposition. The thermal events observed on the DSC curve were exothermic and are according to mass losses evidenced on the TG/DTG curves. The first thermal decomposition was evidenced between 240 and $295^{\circ} \mathrm{C}\left(\mathrm{T}_{\text {peak }}=268^{\circ} \mathrm{C}\right)$ and the second occurred between 295 and $500^{\circ} \mathrm{C}\left(\mathrm{T}_{\text {peak }}=400{ }^{\circ} \mathrm{C}\right)$.

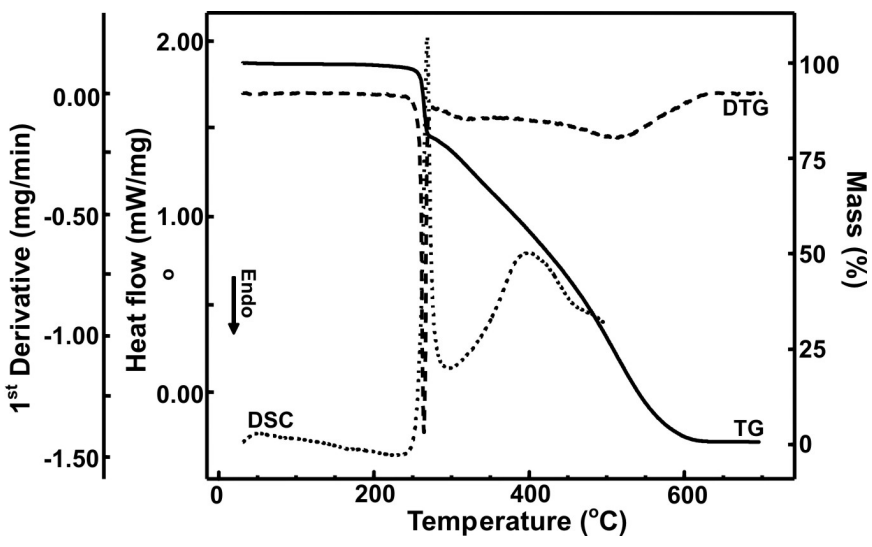

FIGURE 2 - TG/DTG and DSC curves obtained at $10^{\circ} \mathrm{C} / \mathrm{min}$ for the rifampicin sample (polymorph I).

The TG/DTG and DSC rifampicin polymorph II curves are shown in Figure 3. The TG/DTG curves indicated a crystalline form which is thermally stable up to around $195^{\circ} \mathrm{C}$. The thermal decomposition process occurred in three stages. The first occurred rapidly between 195 and $258^{\circ} \mathrm{C}$ with loss of mass of around $11.9 \%$, while the second occurred more slowly between 258 and $440{ }^{\circ} \mathrm{C}$ with mass loss of $27.3 \%$. Finally, the third stage occurred between 440 and $770{ }^{\circ} \mathrm{C}$ with mass loss of $59.5 \%$. There was a small amount of residue of $1.2 \%$ which was partially derived from elementary carbon formed during the second and third step of the thermal decomposition. The thermal events observed on the DSC curve are according to mass losses evidenced on the TG/DTG curves. The DSC curve showed an endothermic event with a heat variation starting at $160{ }^{\circ} \mathrm{C}$ $\left(\mathrm{T}_{\text {peak }}=193.9^{\circ} \mathrm{C}\right)$, followed by three exothermic events $\left(\mathrm{T}_{\text {peak }}^{\text {peak }}=209.4 ; 257.6\right.$ and $\left.420.9^{\circ} \mathrm{C}\right)$. The endothermic event which occurred at $193.9^{\circ} \mathrm{C}\left(\mathrm{T}_{\text {peak }}\right)$ is characteristic of a melting process followed by recrystallization, which in turn is characterized by the exothermic event at $209.4{ }^{\circ} \mathrm{C}\left(\mathrm{T}_{\text {peak }}\right)$. The thermal decomposition process began with the heat liberated from recrystallization which produces polymorph I and proceeded exothermally, as indicated on the DSC curve by the temperature peaks at 257.6 and $420.9^{\circ} \mathrm{C}$.

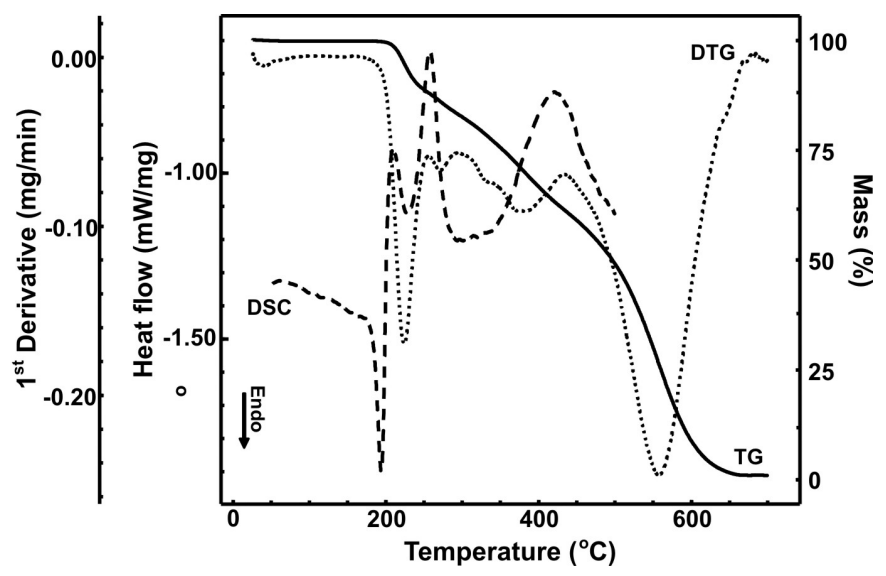

FIGURE 3 - TG/DTG and DSC curves obtained at $10^{\circ} \mathrm{C} / \mathrm{min}$ for the rifampicin sample (polymorph II).

\section{Comparison of the thermal behavior of polymorphic I and II}

From the overlap of the DSC curves of Figure 4, the differences between the two crystalline forms are clearly evident. On the DSC curve (a) of the polymorphic form I (curve a), a smaller number of thermal events (only two) is observed. This form is more thermally stable. The DSC curve showed no fusion of the species, but the process of thermal decomposition began at approximately $245{ }^{\circ} \mathrm{C}$ $\left(\mathrm{T}_{\text {peak }}=268.6^{\circ} \mathrm{C}\right)$. On the other hand, on the DSC curve (b) of the polymorph II four thermal events are evident. The first is endothermic $\left(\mathrm{T}_{\text {peak }}=193.9^{\circ} \mathrm{C}\right)$ due to melting of species. The second event is exothermic and is attributed to a recrystallization $\left(\mathrm{T}_{\text {peak }}=209.4^{\circ} \mathrm{C}\right)$ and corresponds to conversion of polymorphic form II into polymorphic form I. The evidence indicates that a fraction of heat released in 
the process of recrystallization to polymorph I (curve b) is used to initiate the thermal decomposition of the material. This can be concluded because the $\mathrm{T}_{\text {peak }}\left(257.6^{\circ} \mathrm{C}\right)$ of the exothermic event indicative of the first stage of thermal decomposition (curve b) is lower than the $\mathrm{T}_{\text {peak }}\left(268^{\circ} \mathrm{C}\right.$ ) that is indicative of the start of thermal decomposition of polymorph I (curve a). The TG/DTG curves (Figures 2 and 3) showed there is mass loss at the same temperature range where recrystallization occurs and this confirms that the thermal decomposition of the species occurs simultaneously with recrystallization. Other peaks observed at temperatures of $257.6{ }^{\circ} \mathrm{C}$ and $420.9{ }^{\circ} \mathrm{C}$ (curve b) are due to thermal decomposition of polymorph I generated from polymorph II.

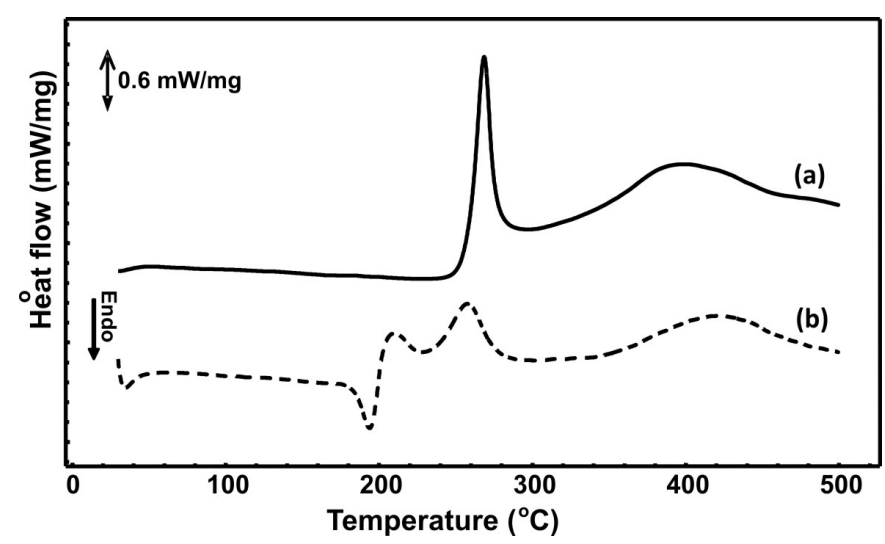

FIGURE 4 - DSC curves obtained at $10^{\circ} \mathrm{C} / \mathrm{min}$ for the rifampicin samples: (a) polymorph I and (b) polymorph II.

\section{Kinetics of thermal decomposition of polymorphs I and II by non-isothermal TG}

According to the OZAWA, 1965, several methods are proposed for obtaining kinetic parameters from thermogravimetric data. There are a variety of relationships

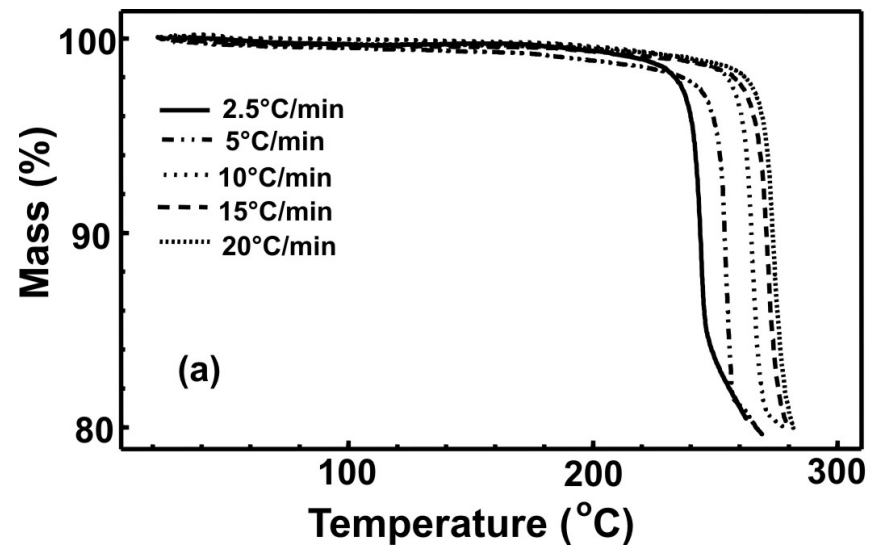

with particular models in differential and integral forms. Specifically, the method described by Ozawa is based on the integral calculations from the equation of Arrhenius.

$$
\mathrm{k}(T)=A \cdot \mathrm{e}^{-\mathrm{Ea} / \mathrm{RT}}
$$

where $\mathrm{A}$ is the frequency factor, $\mathrm{R}$ is the general constant of gases $\left(8.314 \mathrm{~J} \mathrm{~mol}^{-1} \mathrm{~K}^{-1}\right), \mathrm{E}_{\mathrm{a}}$ the activation energy and $\mathrm{T}$ the absolute temperature.

To study the thermal decomposition kinetics for nonisothermal TG of polymorphs I and II of rifampicin, the Ozawa's method available in the software of the thermal analysis system TA 50-WS (Shimadzu) was applied. For application of this method the obtainment of at least three TG curves under different heating rates are required. In this study, five TG curves were obtained at a $\beta$ of $2.5,5$, $7.5,10,15$ and $20^{\circ} \mathrm{C} / \mathrm{min}$.

The overlapping of these TG curves of the polymorphs I and II are illustrated in Figure 5a and 5b, respectively. Ozawa's method was applied to data obtained from the five $\mathrm{TG}$ curves to determine the $\mathrm{E}_{\mathrm{a}}$ at the beginning of the first event of mass loss, corresponding to the process of thermal decomposition that occurs for the polymorph I between 240 and $270{ }^{\circ} \mathrm{C}$, and for the polymorph II between 180 and $210^{\circ} \mathrm{C}$.

For higher heating rates the thermal events are shifted to higher temperatures. Figures $6 \mathrm{a}$ and $6 \mathrm{~b}$ correspond to the heating rates logarithm versus the inverse absolute temperature ( $\log \beta$ vs $1 / \mathrm{T})$, obtained after the processing of data by Ozawa's method, which allowed the kinetic parameters [the activation energy $\left(\mathrm{E}_{\mathrm{a}}\right)$, reaction order (n) and frequency factor (A)] listed in Table I to be obtained for polymorphs I and II. These results confirm the greater stability of polymorph I in comparison with polymorph II.

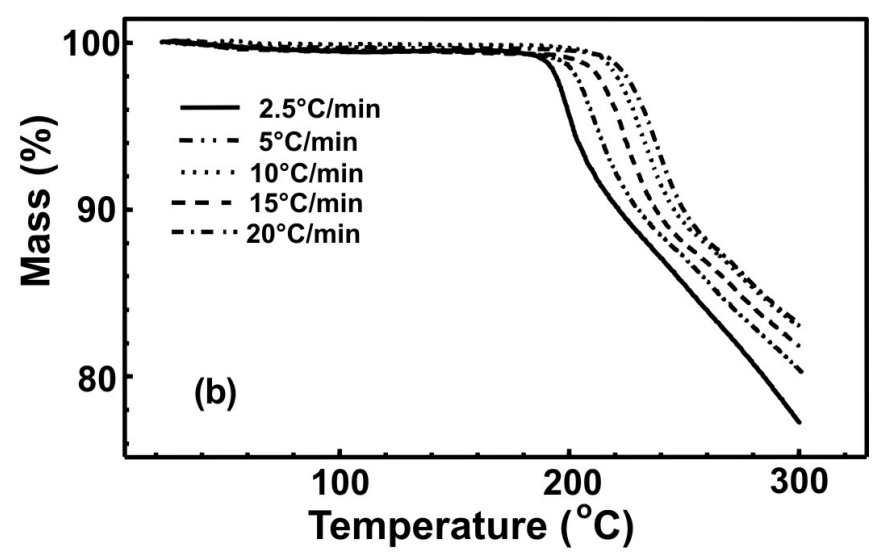

FIGURE 5 - TG curves obtained under dynamic air atmosphere and with different heating rates for the rifampicin samples: (a) polymorph I and (b) polymorph II. 

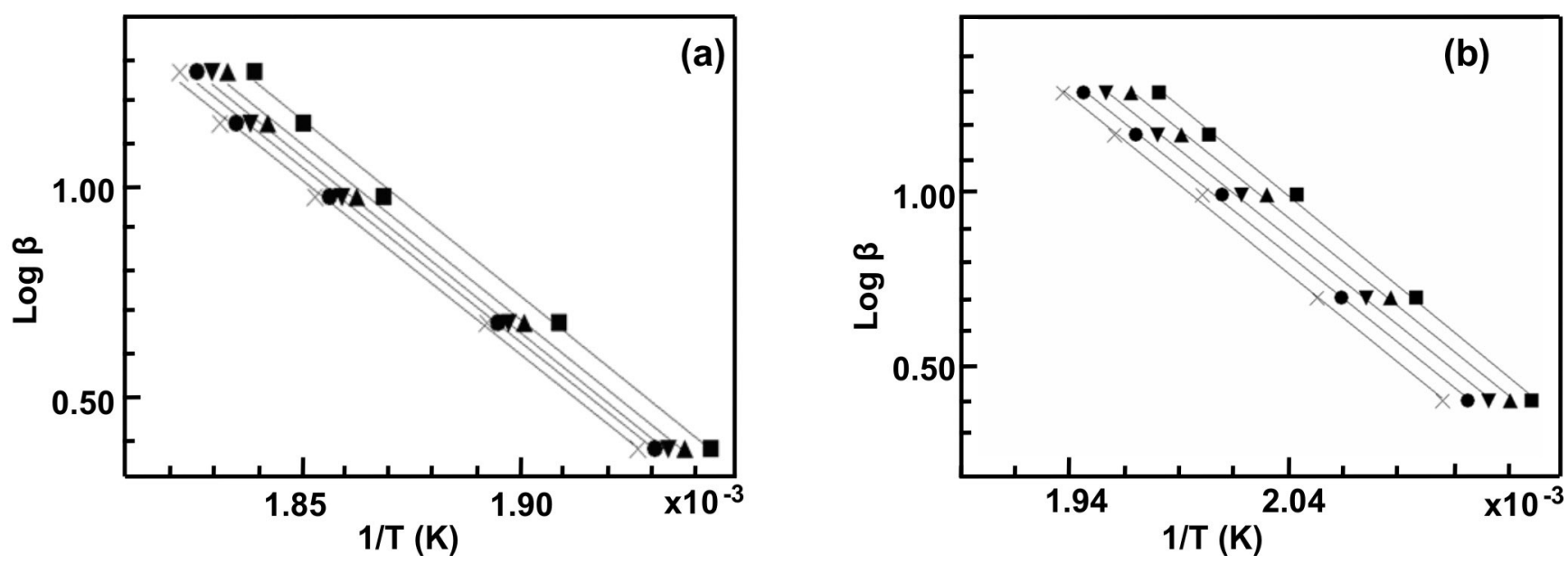

FIGURE 6 - Logarithimic curves of heating rate as a function of inverse of absolute temperature of the rifampicin samples: (a) polymorph I and (b) polymorph II.

TABLE I - Kinetic parameters for the rifampicin polymorphs I and II obtained from the kinetic treatment data of thermal decomposition for non-isothermal TG

\begin{tabular}{lccc}
\hline Sample & \multicolumn{3}{c}{ Kinetic Parameters } \\
\cline { 2 - 4 } & $\mathrm{E}_{\mathrm{a}}(\mathrm{kJ} / \mathrm{mol})$ & $\mathrm{n}$ & $\mathrm{A}\left(\mathrm{min}^{-1}\right)$ \\
\hline Polymorph I & 154 & 0 & $1,73 \times 10^{14}$ \\
Polymorph II & 123 & 1 & $3,50 \times 10^{12}$ \\
\hline
\end{tabular}

Thermal decomposition kinetics of polymorphs I and II by isothermal TG

The isothermal method is commonly used to monitor the reaction kinetics of thermal decomposition in solid state: several plots are obtained of fraction decomposed $(\Delta \mathrm{m})$ versus time $(\mathrm{t})$, keeping the constant temperature $(\mathrm{T})$ in the

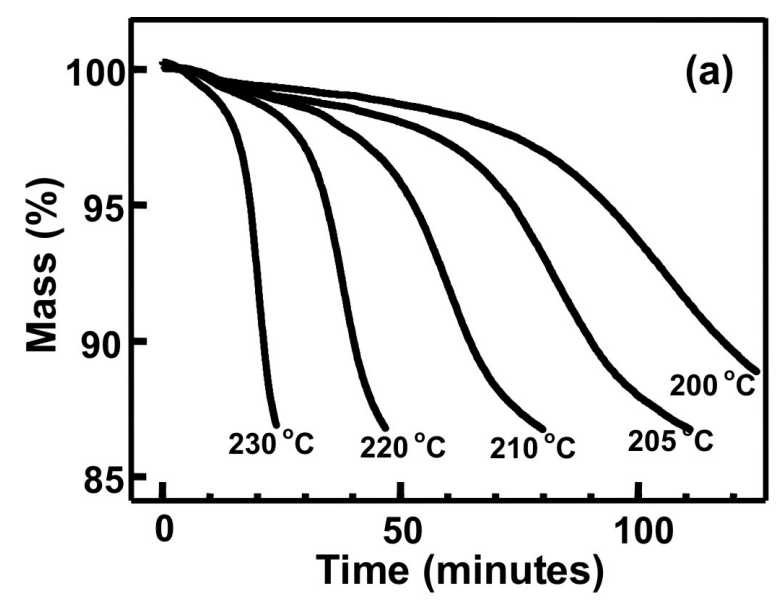

region of interest. The isothermal kinetic method shows that the main difference to the dynamic or non-isothermal method is the possibility of performing measures of $\Delta \mathrm{m}$ as a function of time. In the dynamic kinetic study, the heating rate is used as a variable to obtain each one of the thermogravimetric curves. However, in the isothermal stu$\mathrm{dy}$, the heating rate is always the same and the temperature of the isotherms are varied, and therefore decomposition time is estimated for a defined range of mass loss.

A disadvantage presented by the isothermal method in comparison with the dynamic method, is the relatively long time usually required for data acquisition. The calculation of the activation energy is based on the Arrhenius equation (Equation 4).

The data presented in Figures 7 and 8 show the process of obtaining the values of $\mathrm{E}_{\mathrm{a}}$ using the isothermal method for samples of rifampicin (polymorphs I and II).

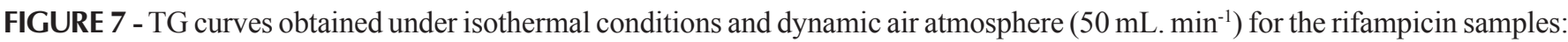
(a) polymorph I and (b) polymorph II. 

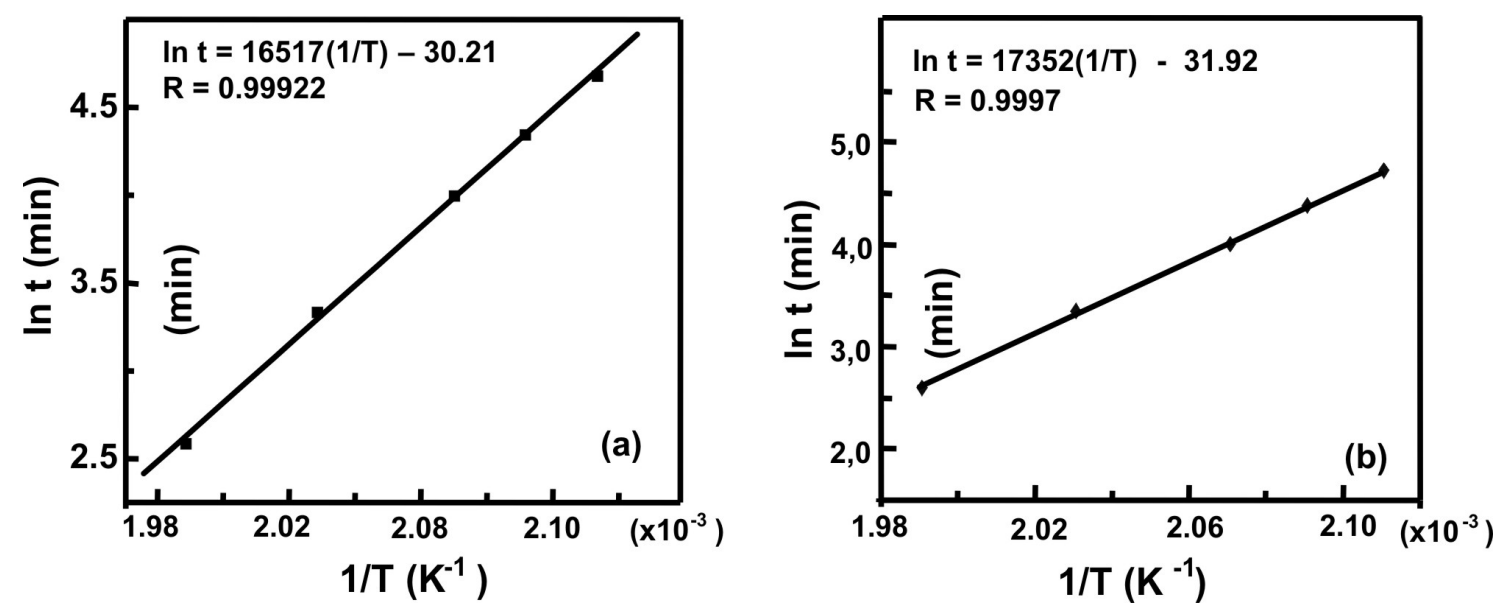

FIGURE 8 - Arrhenius plot, ln t vs 1/T, for thermal decomposition of the rifampicin samples: (a) polymorph I and (b) polymorph II.

For polymorph I, the TG curves (Figure 7a) were obtained by heating the sample at $200,205,210,220$ and $230^{\circ} \mathrm{C}$ and maintained at isothermal conditions under a dynamic atmosphere of air $\left(50 \mathrm{~mL} \mathrm{~min}{ }^{-1}\right)$ for a sufficient time for the mass loss to be at least $10 \%$. For polymorph II, the TG isotherm curves (Figure 7b) were obtained at temperatures of $175,180,185,190$ and $195^{\circ} \mathrm{C}$. These curves show the dependence of the mass loss, according to isotherm temperature: it is evident that the higher the temperature, the lower the time necessary for the same mass loss to occur. Differences can be seen in the profile of the isothermal TG curves between the samples. It was observed that under conditions in which these curves have been obtained, the mass loss for the polymorphic form I occurred more rapidly.

Figures $8 \mathrm{~A}$ and $8 \mathrm{~B}$ show the plots of $\ln \mathrm{t}(\mathrm{min}) \mathrm{vs}$ $1 / \mathrm{T}(\mathrm{K})$, respectively, for polymorphs I and II, from which straight line equations were obtained which correspond to linear regression $(\boldsymbol{y}=\boldsymbol{a x}+\boldsymbol{b})$. The slope of the line is defined by $\boldsymbol{a}$ (slope), and the $\mathrm{E}_{\mathrm{a}}$ can be determined by multiplying $\boldsymbol{a}$ by the general gas constant $\mathrm{R}\left(8.314 \mathrm{~J} \mathrm{~mol}^{-1} \mathrm{~K}^{-1}\right)$.

The values of $\mathrm{E}_{\mathrm{a}}$ were 137 and $144 \mathrm{~kJ} \mathrm{~mol}^{-1}$, respectively, for polymorphs I and II, respectively. The comparison between the values of $\mathrm{E}_{\mathrm{a}}$ found for both methods of evaluation of the kinetics of thermal decomposition showed a distortion. This distortion can be explained by the possibility of transformation of polymorphic form II into polymorphic form I. As in the isothermal method, the data were obtained at temperatures close to those at which the material undergoes melting and recrystallization processes, and favors the formation of a mixture of polymorphs i.e., during the time of the heating at the temperature of the isotherm, the formation of polymorph I may partly occur, which certainly modified the characteristics of the sample under evaluation.

In a bid to understand the thermal behavior of polymorph II and confirm its subsequent transformation into polymorph I, after the processes of melting and recrystallization, the samples of material were heated and maintained at specific isothermal temperatures for 45 minutes. The intermediate products obtained at isotherm temperatures of $170,190,200$ and $210^{\circ} \mathrm{C}$ were isolated for characterization by infrared spectroscopy (IR). One sample was also collected after being kept isothermal for 10 minutes at $200{ }^{\circ} \mathrm{C}$.

The IR spectra of the products collected after heating polymorph II at different temperatures were recorded in the range of wavenumber $4000-400 \mathrm{~cm}^{-1}$. These spectra are illustrated in Figure 9 along with the spectra of polymorphs I and II. From these spectra it was concluded that up to $170{ }^{\circ} \mathrm{C}$ the polymorph II did not undergo any structural changes. However, the IR spectrum of product isolated at $190{ }^{\circ} \mathrm{C}$ is characteristic of polymorphic form I, as occurred with the spectrum of product isolated after 10 minutes of heating at $200{ }^{\circ} \mathrm{C}$. This heating time of 10 minutes is more appropriate to detect the structural change, since at 45 minutes in $\mathrm{T}_{\text {isothermal }}$, partial thermal decomposition of the material already takes place. Figure 10 illustrates the isothermal TG curve at $190{ }^{\circ} \mathrm{C}$. It may be noted that there was a mass loss of about $2.3 \%$ of polymorph II after 45 minutes of heating, confirming the partial thermal decomposition of this species.

\section{CONCLUSIONS}

The studies performed using TG/DTG and DSC techniques revealed a significant difference between the thermal stability of the polymorphic forms I and II of rifampicin, which may be important for drug/excipient compatibility and consequently for the stability of the formulated products. Polymorph II is the metastable form, as shown on the DSC curve, due to melting followed by recrystalliza- 


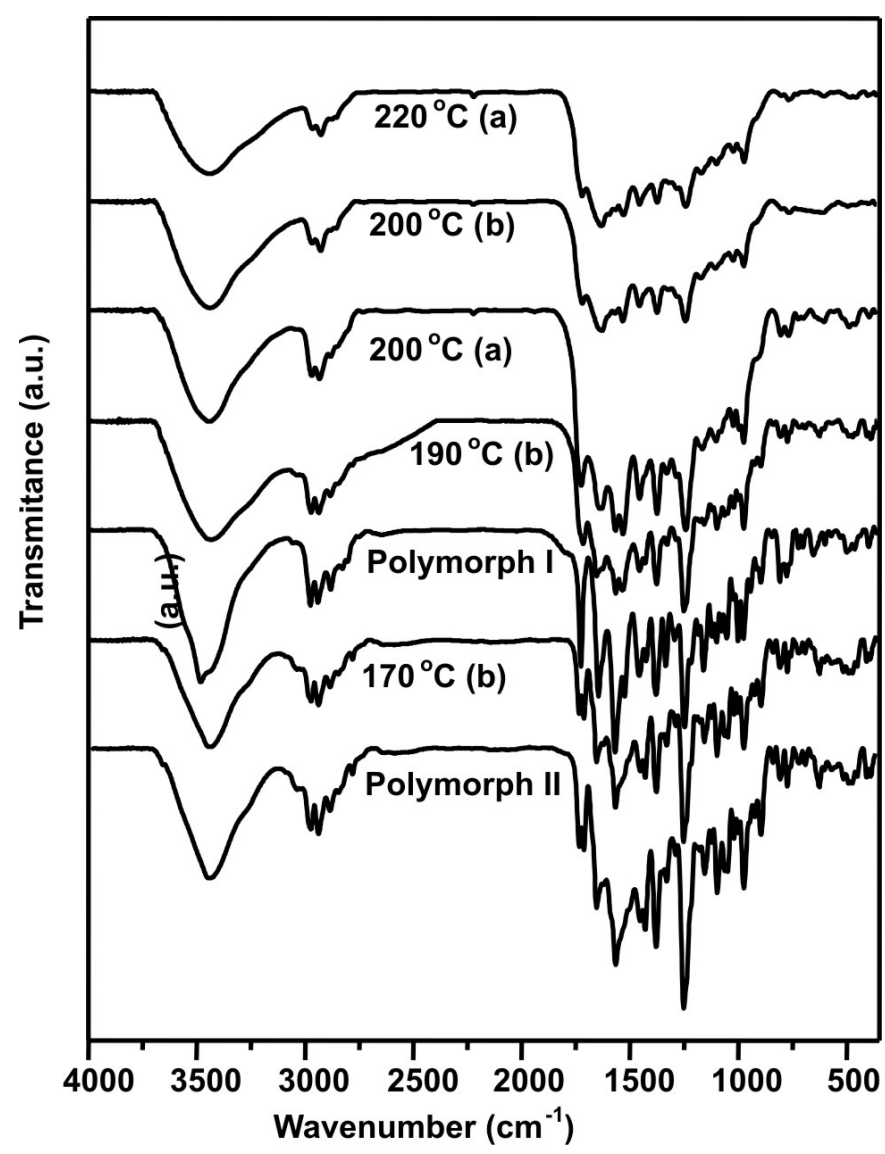

FIGURE 9 - IR spectra of the polymorph I, polymorph II and intermediate products isolated from polymorph II at different temperatures with isotherm time: (a) 10 minutes and (b) 45 minutes.

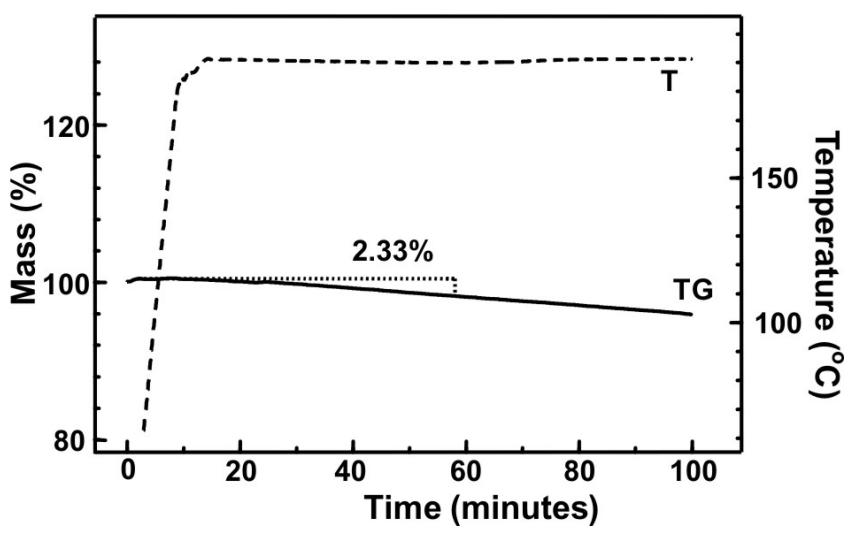

FIGURE 10 - Isothermal TG curve at $190{ }^{\circ} \mathrm{C}$ of the polymorph II sample.

tion as polymorph $\mathrm{I}$. The $\mathrm{E}_{\mathrm{a}}$ obtained from $154 \mathrm{~kJ} / \mathrm{mol}$ for polymorph I and $123 \mathrm{~kJ} / \mathrm{mol}$ for polymorph II by using the Ozawa method are consistent with the higher thermal stability expected for polymorph I. The $\mathrm{E}_{\mathrm{a}}$ of 137 and $144 \mathrm{~kJ} / \mathrm{mol}$ for polymorphs I and II, respectively, determined by isothermal methods, showed distortions. The value of $\mathrm{E}_{\mathrm{a}}$ for polymorph I was expected to be higher than that in polymorph II. This difference may be explained by the metastable characteristic of polymorph II, and because heating in the $\mathrm{T}_{\text {isotherm }}$ is close to its melting point, its partial conversion occurs in the polymorph I. Thus, the results correspond to a mixture of polymorphs, and probably a product of partial thermal decomposition of the species. The use of different polymorphs in a particular design requires care, since this can lead to the production of medicines which are not equivalent due to differences in solubility between them. Also, the conversion of one polymorph to another can occur, as can their interaction with inert excipients of the medicine during processing and/or storage.

\section{ACKNOWLEDGMENTS}

To FURP (for the donation of rifampicin samples), CNPq, Capes and FAPESP.

\section{REFERENCES}

AGRAWAL, S., ASHOKRAJ, Y, BHARATAM, P.V., PILLAI, O, PANCHAGNULA, R. Solid state characterization of rifampicin samples and its biopharmaceutic relevance. Eur. J. Pharm. Sci., v.22, p.127-144, 2004.

ARAÚJO, A. A. S.; STORPIRTIS, S.; MERCURI, L. P.; CARVALHO, F.M.S.; SANTOS FILHO, M.; MATOS, J.R. Thermal analysis of the antiretroviral zidovudine (AZT) and evaluation of the compatibility with excipients used in solid dosage forms. Int. J. Pharm., v.260, p.303-314, 2003.

BACCHI, A., PELIZZI, G., NEBULONI, M., FERRARI, P. Comprehensive study on structure-activity relationships of rifamycins: Discussion of molecular and crystal structure and spectroscopic and spectroscopic and thermochemical properties of rifamycin. J. Med. Chem., v.41, p.2319-2332, 1998.

BUJNOWSKI, K, SYNORADZKI, L. DINJUS, E., ZEVACO, T., AUGUSTYNOWICZ-KOPEC, E., ZWOLSKA, Z. Rifamycin antibiotics-new compounds and synthetic methods. Part 1: Study of the reaction of 3-formylrifamycin SV with primary alkylamines or ammonia. Tetrahedron, v.59, p.1885-1893, 2003.

CARVALHO, W. S., MIRANDA, S.S., PESQUERO, J.L., GOMES, M.A. Diagnóstico de resistência do Mycobacterium tuberculosis à rifampicina utilizando-se da reação em cadeia da polimerase. Rev. Bras. Ciênc. Farm., v.43, p.31-38, 2007. 
CIDES, L.C.D., ARAÚJO, A.A.S., SANTOS-FILHO, M., MATOS, J.R. Thermal behaviour, compatibility study and decomposition kinetics of glimepiride under isothermal and non-isotermal conditions. J. Therm. Anal. Calorim., v.84, p.441-445, 2006.

FORD, J.L.; TIMMINS, P. Pharmaceutical thermal analysis: Techniques and applications. New York: John Wiley \& Sons, 1989. p.108-309.

GIRON, D. Contribution of thermal methods and related techniques to the rational development of pharmaceuticalsPart 1. Pharm. Sci. Technol. Today, v.1, p.191-199, 1998a.

GIRON, D. Contribution of thermal methods and related techniques to the rational development of pharmaceuticalsPart 2. Pharm. Sci. Technol. Today, v.6, p.262-268, 1998 b.

HENWOOD, S.Q., DE VILLIERS, M.M., LIEBENBERG, W., LÖTHER, A.P. Solubility and dissolution properties of generic rifampicin raw materials. Drug Dev. Ind. Pharm., v.26, p.403-408, 2000.

MATOS, J.R.; MERCURI, L.P.; ARAUJO, G.L.B. Aspectos gerais relativos ao desenvolvimento farmacotécnico de medicamento: análise térmica aplicada a fármacos e medicamentos. In: STORPIRTIS, S.; GONÇALVES, J.E.; CHIANN, C.; GAI, M.N. (Eds.). Biofarmacotécnica. Rio de Janeiro: Guanabara Koogan, 2009. p.32-65.

OZAWA, T. A new method of analyzing thermogravimetric data. Bull. Chem. Soc. Jpn., v.38, 1881-1886, 1965.

PANCHAGNULA, R., AGRAWAL, S. Biopharmaceutic and pharmacokinetics aspects of variable bioavailability of rifampicin. Int. J. Pharm., v.271, p.1-4, 2004.

PARISE FILHO, R.; ARAUJO, A. A. S.; SANTOS FILHO, M.; MATOS, J.R.; SILVEIRA, M. A. B.; BRANDT, C. A. . Thermoanalytical characterization of potentially schistosomicide polymeric derivatives. J. Therm. Anal. Calorim., v.75, p.487-494, 2004.
PELIZZA, G., NEBULONI, M., FERRARI, P., GALLO, G.G. Polymorphism of rifampicin. Farmaco (Sci), v.32, p.471481, 1977.

ROUQUEROL, J.; WADSÖ, I.; LEVER, T.J.; HAINES, P.J. Developments in nomenclature. In: BROWN, M., GALLAGHER, P. (Eds.). Handbook of thermal analysis and calorimetry. Recent advances, techniques and applications. Amsterdam: Elsevier, 2007. v.5, p 21-62.

SALTINI, C. Chemotherapy and diagnosis of tuberculosis. Resp. Med., v.100, p.2085-2097, 2006.

SINGH, S., MARIAPPAN, T. T., SANKAR, R., SARDA, N. SINGH, B. A critical review of probable reasons for the poor/variable bioavailability of rifampicin from antitubercular fixed-dose combination (FDC) products, and the likely solutions to the problem. Int. J. Pharm., v.228, p.5-17, 2001.

VENKATARAM, S.; KHOHLOKWANE, M.; WALLIS, S.H., Differential scanning calorimetry as a quick scanning technique for solid state stability studies, Drug Dev. Ind. Pharm. v.21, p.847-855, 1995

WORLD HEALTH ORGANIZATION. Global tuberculosis control: surveillance, planning, financing. Genebra: WHO, 2006. $77 \mathrm{p}$.

WORLD HEALTH ORGANIZATION. Model list of essential medicines. 5.ed. Genebra: WHO, 2007. 61 p.

ZHANG, Y., The magic bullets and tuberculosis drug targets. Annu. Rev. Pharmacol. Toxicol., v.45, p.529-64, 2005.

Received for publication on $16^{\text {th }}$ October 2007 Accepted for publication on $29^{\text {th }}$ March 2009 